\title{
The Prevalence of Hypertension among Croatian Hospitalized Coronary Heart Disease Patients
}

\author{
Hrvoje Vražić ${ }^{1}$, Jozica Šikić ${ }^{1,2}$, Tomo Lucijanić ${ }^{1,3}$, Miroslav Raguž ${ }^{1}$, Antica Romiće ${ }^{4}$, Nediljko Jukić ${ }^{5}$, \\ Janko Grman ${ }^{6}$, Aleksandar Knežević ${ }^{7}$, Mario Ivanuša ${ }^{8,9}$ and Mijo Bergovec ${ }^{1,3}$ \\ ${ }^{1}$ University of Zagreb, Dubrava University Hospital, Department of Internal Medicine, Division of Cardiology, Zagreb, Croatia \\ ${ }^{2}$ University of Zagreb, »Sveti Duh« University Hospital, Department of Internal Medicine, Division of Cardiology, Zagreb, Croatia \\ ${ }^{3}$ University of Zagreb, School of Medicine, Zagreb, Croatia \\ ${ }^{4}$ Dubrovnik General Hospital, Department of Internal Medicine, Division of Cardiology, Dubrovnik, Croatia \\ ${ }^{5}$ Pula General Hospital, Department of Internal Medicine, Division of Cardiology, Pula, Croatia \\ ${ }^{6}$ Karlovac General Hospital, Department of Internal Medicine, Division of Cardiology, Karlovac, Croatia \\ 7 Zadar General Hospital, Department of Internal Medicine, Division of Cardiology, Zadar, Croatia \\ ${ }^{8}$ Bjelovar General Hospital, Department of Internal Medicine, Division of Cardiology, Bjelovar, Croatia \\ ${ }^{9}$ Institute for Cardiovascular Prevention and Rehabilitation, Zagreb, Croatia
}

\begin{abstract}
A B S T R A C T
The aim of this article was to investigate the prevalence of hypertension with selected anthropometric variables in a sample of hospitalized coronary heart disease (CHD) patients in Croatia. This study investigated patients hospitalized in the period of October $1^{\text {st }} 2007$ until January $7^{\text {th }} 2010$ because of acute or chronic CHD in various hospitals in Croatia ( $N=1,298)$. Prevalence of hypertension in surveyed patient population was high: $70.1 \%$ of participants had raised blood pressure $(B P)$ or previously diagnosed hypertension. Men had statistically significantly higher mean diastolic BP values than women (78.91 \pm 8.97 vs. $77.12 \pm 10.61 \mathrm{mmHg}, p=0.011)$. Prevalence of hypertension was statistically significantly more frequent in women ( $80.6 \%$ vs. $65.8 \%, p<0.001$ ). Hypertension still represents an important problem among hospitalized Croatian CHD patients. Its prevalence, unfortunately, continues to increase in this population, suggesting that there is still great potential for improvement of preventive cardiology standards and measures that have already been undertaken.
\end{abstract}

Key words: coronary heart disease, cardiovascular risk factor, hypertension, Croatia, primary prevention, secondary prevention

\section{Introduction}

Hypertension is one of most thoroughly investigated cardiovascular risk factors, which has been shown to cause increased mortality from coronary heart disease (CHD) and stroke ${ }^{1-4}$, therefore it can be considered as one of the most preventable causes of premature death ${ }^{5}$ as it represents an independent risk factor for the development of cardiovascular disease $(\mathrm{CVD})^{6}$. It has been demonstrated that this risk continually increases as the values of blood pressure (BP) surpass that what is considered "normal limit (for example persons aged 40-70 years have doubled risk of development of cardiovascular disease for either increase of systolic $\mathrm{BP}$ of $20 \mathrm{mmHg}$ or diastolic BP of $10 \mathrm{mmHg}^{4}$. Furthermore, it has been shown that research of hypertension and other risk factors that are connected with it in different populations represents one of basic preconditions for planning of effective prevention programmes based on evidence-based medicine principles in order to prevent devastating effects of arterial hypertension ${ }^{7,8}$. INTERHEART study (A global study of risk factors in acute myocardial infarction) showed that the presence of increased BP was responsible for $18 \%$ of population attributive risk for oc- 
currence of first myocardial infarction ${ }^{9}$. As numerous studies have shown beneficial effects of reduction of BP values, the importance of lifelong good $\mathrm{BP}$ control is continuously stressed, for it has also been observed that the contribution of hypertension as a risk factor is additionally potentiated in persons with other risk factors or target organ damage. Therefore it is clear why this approach is also used in assessment of one's total cardiovascular risk. However, it should be noted that in persons who already have CVD or have high risk for development of CVD, target BP values are somewhat lower than those advised for the general population. This is due to the fact that it has been reported that the risk for occurrence or advancement of CVD is progressively increasing with BP values higher than $110 / 75 \mathrm{mmHg}^{10}$. Similar trend has also been observed in persons that are known to have $\mathrm{CHD}^{11}$. The answer to the question on what the BP target values in those patients should be like has been provided by large international clinical trials HOPE (Heart Outcomes Prevention Evaluation), EUROPA (European trial on reduction Of cardiac events with perindopril in patients with stable coronary artery disease) and CAMELOT (Comparison of Amlodipine vs. Enalapril to Limit Occurrences of Thrombosis) which have all shown that $\mathrm{BP}$ reduction below previously recommended values provides further benefits in patients with high risk ${ }^{12-14}$.

According to the 2007 Guidelines from the European Society of Cardiology (ESC) it is recommended for patients with CVD that, if possible, the $\mathrm{BP}$ values should be $<130 / 80 \mathrm{mmHg}$, while the values of $<140 / 90 \mathrm{mmHg}$ are recommended for the primary prevention ${ }^{15,16}$.

Published data on Croatian general population report quite heterogeneous prevalences of hypertension in Croatia, which are ranging from $16.7 \%$ and $54 \%$, depending on which methodology was used and in which year the survey was conducted ${ }^{17-20}$. Most recently published data are those from the Croatian Adult Health Survey (CAHS) which was conducted in 2003 in the general population, reporting hypertension prevalence (mean systolic BP values $\geq 140 \mathrm{mmHg}$ or mean diastolic $\mathrm{BP}$ values $\geq 90$ $\mathrm{mmHg}$ ) in men of $40.5 \%$ and in women $34.9 \%{ }^{21}$.

\section{Materials and Methods}

The survey included 1,298 patients hospitalized between October $1^{\text {st }} 2007$ and January $7^{\text {th }} 2010$ for acute or chronic CHD in various hospitals in Croatia. It was performed in the above mentioned period in Dubrava University Hospital (Zagreb), Sveti Duh University Hospital (Zagreb), Bjelovar General Hospital, Čakovec General Hospital, Karlovac General Hospital, Koprivnica General Hospital, Slavonski Brod General Hospital, Varaždin General Hospital, Rijeka University Hospital Centre, Pula General Hospital, Split University Hospital Centre, Dubrovnik General Hospital and Zadar General Hospital.

A special questionnaire was produced for this study which allowed recording of required data. Questionnaire was made after series of consultations with experts and literature and it was compiled by model of large clinical trials conducted in Europe and Croatia [INTERHEART ${ }^{9}$, EUROASPIRE (European action on secondary prevention by intervention to reduce events) $\mathrm{I}^{22}$ and $\mathrm{II}^{23}, \mathrm{EH}-$ -UH (Epidemiology of hypertension in Croatia) ${ }^{24}$, TASPIC-CRO V (Treatment and secondary prevention of ischemic coronary events in Croatia ${ }^{25}$ ]. This allowed the investigators to be able to efficiently compare results. Most of the questions had multiple answers offered in advance to acquire greater accuracy. Data was collected on patient history (personal and family history), age, sex and information on cardiovascular risk factors and discharge diagnoses. Physical examination was performed, results of which were recorded - BP was measured twice on both arms, after the patient had been sitting for at least 10 minutes. Mean values of measured BP were used for data analysis.

Patients were considered to have hypertension when they fulfilled one of two criteria: either they had previously diagnosed hypertension (and were taking medications) or they had raised $\mathrm{BP}$ values at interview. The BP values that were considered as raised at interview (and therefore indicative of hypertension) were either $\geq 140$ $\mathrm{mmHg}$ for systolic ( $\geq 130 \mathrm{mmHg}$ in diabetics), or $\geq 90$ $\mathrm{mmHg}$ for diastolic BP ( $\geq 80 \mathrm{mmHg}$ in diabetics).

Data were collected by physicians or trained personnel (nurse), coded and entered into the electronic file. Confidentiality of data was ensured in accordance with current applicable codes, declarations and other provisions. The results are shown in tables, and for quantitative variables descriptive statistics were done with appropriate measures of central tendency and variability (mean, standard deviation, medians, associated interquartile ranges). Normal distribution of quantitative variables was tested by Kolmogorov-Smirnov test, and then appropriate parametric (t-test for independent samples and analysis of variance - ANOVA) or nonparametric tests (Mann-Whitney U-test, Kruskal-Wallis test) were used. The $\chi^{2}$-test was also used.

Statistically significant results were considered those with $\mathrm{p}$ values $<0.05$. Statistical analysis was made using the software PASW version 17.02 (Chicago Inc., IL, www. spss.com).

\section{Results}

A total of 898 subjects had hypertension (70.1\%), while 383 subjects $(29.9 \%)$ had BP values within normal range. Data on $\mathrm{BP}$ values was not available for 17 subjects. Mean value of $\mathrm{BP}$ was $128.30 \pm 17.37 \mathrm{mmHg}$ (systolic) and $78.39 \pm 9.50 \mathrm{mmHg}$ (diastolic).

Men had statistically significantly higher mean diastolic BP values than women $(p=0.011$, Table 1 , Mann Whitney U test).

Hypertension was statistically significantly more frequent in women $\left(\mathrm{p}<0.001\right.$, Table $2, \chi^{2}$-test $)$. 
H. Vražić et al.: Hypertension among Croatian CHD Patients, Coll. Antropol. 36 (2012) Suppl. 1: 217-221

TABLE 1

COMPARISON OF MEAN ARTERIAL BLOOD PRESSURES (SYSTOLIC AND DIASTOLIC) ACCORDING TO SEX

\begin{tabular}{|c|c|c|c|c|c|c|c|c|c|c|}
\hline \multirow{2}{*}{$\begin{array}{l}\text { Measured value } \\
(\mathrm{mmHg})\end{array}$} & \multirow{2}{*}{ Sex } & \multirow{2}{*}{$\mathrm{N}$} & \multirow{2}{*}{$\overline{\mathrm{X}}$} & \multirow{2}{*}{$\mathrm{SD}$} & \multirow{2}{*}{ Min. } & \multicolumn{3}{|c|}{ Percentiles } & \multirow{2}{*}{ Max. } & \multirow{2}{*}{$\mathrm{p}$} \\
\hline & & & & & & 25. & 50. (Median) & 75. & & \\
\hline \multirow{2}{*}{ Systolic } & Men & 909 & 127.89 & 16.56 & 87.50 & 116.25 & 127.50 & 138.75 & 182.50 & \multirow{2}{*}{0.245} \\
\hline & Women & 372 & 129.29 & 19.20 & 80.00 & 116.25 & 128.75 & 141.25 & 192.50 & \\
\hline \multirow{2}{*}{ Diastolic } & Men & 909 & 78.91 & 8.97 & 51.00 & 72.50 & 80.00 & 83.75 & 121.25 & \multirow{2}{*}{0.011} \\
\hline & Women & 372 & 77.12 & 10.61 & 42.50 & 70.00 & 80.00 & 82.50 & 116.25 & \\
\hline
\end{tabular}

Mann-Whitney U-test was used, $\mathrm{p}<0.05$ is considered statistically significant

$\mathrm{mmHg}$ - millimetres of mercury, $\mathrm{N}$ - number, SD - standard deviation, Min. - minimum, Max. - maximum, $\overline{\mathrm{X}}-\mathrm{Mean}$

TABLE 2

COMPARISON OF RAISED ARTERIAL BLOOD PRESSURE OR HYPERTENSION ACCORDING TO SEX

\begin{tabular}{lccr}
\hline \multirow{2}{*}{ Sex } & \multicolumn{2}{c}{$\begin{array}{c}\text { Raised arterial blood pressure } \\
\text { or hypertension }\end{array}$} & \multirow{2}{*}{ Total } \\
\cline { 2 - 3 } & \multicolumn{2}{c}{ No } & Yes \\
\hline Men & $311(34.2 \%)$ & $598(65.8 \%)$ & $909(100.0 \%)$ \\
Women & $72(19.4 \%)$ & $300(80.6 \%)$ & $372(100.0 \%)$ \\
Total & $383(29.9 \%)$ & $898(70.1 \%)$ & $1281(100.0 \%)$ \\
\hline
\end{tabular}

$\chi^{2}=27.806 ; \mathrm{df}=1 ; \mathrm{p}<0.001$

$\chi^{2}$-test was used, $\mathrm{p}<0.05$ is considered statistically significant

$\%$ - percent, $\mathrm{df}$ - degrees of freedom

\section{Discussion}

This article presents the available data on the prevalence of hypertension among Croatian hospitalized CHD patients. Hypertension is one of interim cardiovascular risk factors (much like overweight and obesity), and therefore represents a more complex risk factor in comparison to behavioural factors that are completely dependent on one's behaviour, as there are many factors that influence its onset and reduction ${ }^{26}$. Its role as one of today's most important preventable causes of premature death is well recognized and it is an independent risk factor for development of CVD ${ }^{5}$. INTERHEART study showed that the presence of increased BP was responsible for $18 \%$ of population attributive risk for occurrence of first myocardial infarction ${ }^{9}$. As numerous studies have shown beneficial effects of reduction of $\mathrm{BP}$ values, the importance of lifelong optimal BP control is continuously stressed as an important goal in order to reduce cardiovascular morbidity and mortality. The 2007 ESC Guidelines recommend for patients with CVD that, if possible, the $\mathrm{BP}$ values should be $<130 / 80 \mathrm{mmHg}$, while the values of $<140 / 90 \mathrm{mmHg}$ are recommended for the primary prevention ${ }^{15,16}$. When analysing data from this study, in order to allow comparisons with available data from two other relevant studies which also examined this risk factor in Croatian patients with CHD (TASPIC-CRO V ${ }^{25}$ which was performed in years 2002 and 2003 and EURO-
ASPIRE III ${ }^{27}$ which was performed in 22 European countries in 2006, one of the countries that participated was also Croatia), it was necessary to use the cut-off values from older Guidelines, and therefore the BP values that were considered as raised were either $\geq 140 \mathrm{mmHg}$ for systolic BP ( $\geq 130 \mathrm{mmHg}$ in diabetics), or $\geq 90 \mathrm{mmHg}$ for diastolic BP ( $\geq 80 \mathrm{mmHg}$ in diabetics).

According to those criteria, including also patients with previously diagnosed hypertension, 898 subjects (70.1\%) had hypertension in this study. This represents an increase in prevalence, as in TASPIC-CRO V the prevalence of this risk factor was $66 \%{ }^{25}$ and in EUROASPIRE III it was $56 \%$ for the whole sample in 22 European countries and $62 \%$ in the Croatian sample ${ }^{27}$. Our data shows that there is an unfavourable trend of further increase of already high prevalence of hypertension among Croatian patients with CHD, which remains higher than European average. Bearing in mind the above mentioned deleterious effects of hypertension on cardiovascular morbidity and mortality, one can only imagine that this will bring further unfavourable trends on cardiovascular morbidity and mortality in Croatia in coming years.

Literature shows that both systolic and diastolic BP values represent an important risk factor for $\mathrm{CHD}$ (which is especially true in older persons), but isolated systolic hypertension is also an important risk factor for the development of CHD and stroke ${ }^{28,29}$. The exact effect of hypertension can be difficult to measure, as it has also been shown that when assessing cardiovascular risk, one needs to take into account not just the current values of BP, but also previous values, as well as degree and duration of hypertension. In this study, men had statistically significantly higher values of diastolic BP when compared to women. Women had somewhat higher mean systolic BP values when compared to men; however this difference did not achieve statistical significance (Table 1).

Hypertension is statistically significantly more frequent in women when compared to men $(\mathrm{p}<0.001$, Table 2$)$, where as much as $80.6 \%$ of female CHD patients had this risk factor, as compared to $65.8 \%$ of male CHD patients. Although it has also been shown already in TASPIC-CRO $\mathrm{V}$ that hypertension is more frequently present in female CHD patients ( $76 \%$ in females vs. $62 \%$ in males), it is important to note that the prevalence of hypertension in 
both sexes was lower ${ }^{25}$, and this represents a further warning sign when it comes to assessment of prevention and treatment of hypertension in Croatia.

These data show that hypertension still represents an important problem among Croatian CHD patients. Its prevalence, unfortunately, continues to increase in this population, suggesting that there is still great potential for improvement of preventive cardiology standards and measures that have already been undertaken. There is a need for more effective prioritized interventions targeting lifestyle changes and better control of hypertension as an established cardiovascular risk factor, as it can be expected that without this, the future of Croatian CHD patients will be marked by increased cardiovascular morbidity and mortality.

\section{Acknowledgements}

This study was supported by the Ministry of Science, Education and Sports of the Republic of Croatia, project number 108-1080135-126 (Risk factors by region in hospitalised coronary heart disease patients, led by prof. Mijo Bergovec) which is a part of a programme of projects number 1080135 (Regionalism, dynamics of cardiovascular risk factors and health interventions, led by prof. Mijo Bergovec).

\section{R E F E R E N C E S}

1. THE POOLING PROJECT RESEARCH GROUP, J Chronic Dis, 31 (1978) 201. - 2. NEATON JD, BLACKBURN H, JACOBS D, KULLER L, LEE DJ, SHERWIN R, SHIH J, STAMLER J, WENTWORTH D, Arch Intern Med, 152 (1992) 1490. - 3. MIURA K, DAVIGLUS ML, DYER AR, LIU K, GARSIDE DB, STAMLER J, GREENLAND P, Arch Intern Med, 161 (2001) 1501. - 4. LEWINGTON S, CLARKE R, QIZILBASH N, PETO R, COLLINS R, PROSPECTIVE STUDIES COLLABORATION, Lancet, 360 (2002) 1903. - 5. GELEIJNSE JM, KOK FJ, GROBBEE DE, Eur J Public Health, 14 (2004) 235. - 6. CHOBANIAN AV, BAKRIS GL, BLACK HR, CUSHMAN WC, GREEN LA, IZZO JL JR, JONES DW, MATERSON BJ, OPARIL S, WRIGHT JT JR, ROCCELLA EJ, NATIONAL HEART, LUNG, AND BLOOD INSTITUTE JOINT NATIONAL COMMITTEE ON PREVENTION, DETECTION, EVALUATION, AND TREATMENT OF HIGH BLOOD PRESSURE, NATIONAL HIGH BLOOD PRESSURE EDUCATION PROGRAM COORDINATING COMMITTEE, JAMA, 289 (2003) 2560. - 7. WHITWORTH JA; WORLD HEALTH ORGANIZATION, INTERNATIONAL SOCIETY OF HYPERTENSION WRITING GROUP, J Hypertens, 21 (2003) 1983. - 8. HE J, MUNTNER P, CHEN J, ROCCELLA EJ, STREIFFER RH, WHELTON PK, Arch Intern Med, 162 (2002) 1051. - 9. YUSUF S, HAWKEN S, OUNPUU S, DANS T, AVEZUM A, LANAS F, MCQUEEN M, BUDAJ A, PAIS P, VARIGOS J, LISHENG L, INTERHEART STUDY INVESTIGATORS, Lancet, 364 (2004) 937. - 10. PASTOR-BARRIUSO R, BANEGAS JR, DAMIAN J, APPEL LJ, GUALLAR E, Ann Intern Med, 139 (2003) 731. - 11. SIPAHI I, TUZCU EM, SCHOENHAGEN P, WOLSKI KE, NICHOLLS SJ, BALOG C, CROWE TD, NISSEN SE, J Am Coll Cardiol, 48 (2006) 833. - 12. YUSUF S, SLEIGHT P, POGUE J, BOSCH J, DAVIES R, DAGENAIS G, N Engl J Med, 342 (2000) 145. — 13. FOX KM, EUROPEAN TRIAL ON REDUCTION OF CARDIAC EVENTS WITH PERINDOPRIL IN STABLE CORONARY ARTERY DISEASE INVESTIGATORS, Lancet, 362 (2003) 782. - 14. NISSEN SE, TUZCU EM, LIBBY P, THOMPSON PD, GHALI M, GARZA D, BERMAN L, SHI H, BUEBENDORF E, TOPOL EJ, CAMELOT INVESTIGATORS, JAMA, 292 (2004) 2217. - 15. GRAHAM I, ATAR D, BORCH-JOHNSEN K, BOYSEN G, BURELL G, CIFKOVA R, DALLONGEVILLE J, DE BACKER G, EBRAHIM S, GJELSVIK B, HERRMANN-LINGEN C, HOES A, HUMPHRIES S, KNAPTON M, PERK J, PRIORI SG, PYORALA K, REINER Z, RUILOPE L, SANS-MENENDEZ S, SCHOLTE OP REIMER W, WEISSBERG P, WOOD D, YARNELL J, ZAMORANO JL, WALMA E, FITZGERALD T, COONEY MT, DUDINA A, EUROPEAN SOCIETY OF CARDIOLOGY (ESC) COMMITTEE FOR PRACTICE GUIDELINES (CPG), Eur Heart J, 28 (2007) 2375. - 16. GRAHAM I, ATAR D, BORCH-JOHNSEN K, BOYSEN G, BURELL G, CIFKOVA R, DALLONGEVILLE J, DE BACKER G, EBRAHIM S, GJELSVIK B, HERRMANN-LINGEN C, HOES A, HUMPHRIES S, KNAPTON M, PERK J, PRIORI SG, PYORALA K, REINER Z, RUILOPE L, SANS-MENENDEZ S, OP REIMER WS,

WEISSBERG P, WOOD D, YARNELL J, ZAMORANO JL, WALMA E, FITZGERALD T, COONEY MT, DUDINA A, VAHANIAN A, CAMM J, DE CATERINA R, DEAN V, DICKSTEIN K, FUNCK-BRENTANO C, FILIPPATOS G, HELLEMANS I, KRISTENSEN SD, MCGREGOR K, SECHTEM U, SILBER S, TENDERA M, WIDIMSKY P, ZAMORANO JL, ALTINER A, BONORA E, DURRINGTON PN, FAGARD R, GIAMPAOLI S, HEMINGWAY H, HAKANSSON J, KJELDSEN SE, LARSEN L, MANCIA G, MANOLIS AJ, ORTH-GOMER K, PEDERSEN T, RAYNER M, RYDEN L, SAMMUT M, SCHNEIDERMAN N, STALENHOEF AF, TOKGÖZOGLU L, WIKLUND O, ZAMPELAS A, EUROPEAN SOCIETY OF CARDIOLOGY (ESC), EUROPEAN ASSOCIATION FOR CARDIOVASCULAR PREVENTION AND REHABILITATION (EACPR), COUNCIL ON CARDIOVASCULAR NURSING, EUROPEAN ASSOCIATION FOR STUDY OF DIABETES (EASD), INTERNATIONAL DIABETES FEDERATION EUROPE (IDF-EUROPE), EUROPEAN STROKE INITIATIVE (EUSI), SOCIETY OF BEHAVIOURAL MEDICINE (ISBM), EUROPEAN SOCIETY OF HYPERTENSION (ESH), WONCA EUROPE (EUROPEAN SOCIETY OF GENERAL PRACTICE/FAMILY MEDICINE), EUROPEAN HEART NETWORK (EHN), EUROPEAN ATHEROSCLEROSIS SOCIETY (EAS), Eur J Cardiovasc Prev Rehabil, 14 (2007) S1. 17. TUREK S, RUDAN I, SMOLEJ-NARANCIC N, SZIROVICZA L, CUBRILO-TUREK M, ZERJAVIC-HRABAK V, RAK-KAIC A, VRHOVSKI-HEBRANG D, PREBEG Z, LJUBICIC M, JANICIJEVIC B, RUDAN P, Coll Antropol, 25 (2001) 77. - 18. MIMICA M, CERIC B, KULCAR Z, Lijec Vjesn, 103 (1981) 533. - 19. VULETIC S, BANTIC Z, DEZELIC D, DEZELIC N, IVANKOVIC D, JAKSIC Z, JURESA V, KELNERIC D, KERN J, KISIC M, Lijec Vjesn, 106 (1984) 443. — 20. JELAKOVIC B, KUZMANIC D, RONCEVIC T, BORSO G, LAGANOVIC M, VDOVIC M, Lijec Vjesn, 122 (2000) 192. - 21. ERCEG M, KERN J, BABIC-ERCEG A, IVICEVIC-UHERNIK A, VULETIC S, Coll Antropol, 33 Suppl 1 (2009) 19. - 22. EUROASPIRE STUDY GROUP, Eur Heart J, 18 (1997) 1569. — 23. EUROASPIRE II STUDY GROUP, Eur Heart J, 22 (2001) 554. 24. JELAKOVIC B, ZELJKOVIC-VRKIC T, PECIN I, DIKA Z, JOVANOVIC A, PODOBNIK D, SMUC T, GAMBERGER D, KATIC K, KASNER M, KUZMANIC D; EH-UH ISTRAZIVACKE SKUPINE, Acta Med Croatica, 61 (2007) 287. - 25. REINER Z, MIHATOV S, MILICIC D, BERGOVEC M, PLANINC D, TASPIC-CRO STUDY GROUP INVESTIGATORS, Eur J Cardiovasc Prev Rehabil, 13 (2006) 646. - 26. MULTIFACTORIAL TRIAL IN THE PREVENTION OF CORONARY HEART DISEASE STUDY GROUP, Eur Heart J, 3 (1982) 184. — 27. KOTSEVA K, WOOD D, DE BACKER G, DE BACQUER D, PYÖRÄLÄ K, KEIL U, EUROASPIRE STUDY GROUP, Eur J Cardiovasc Prev Rehabil, 16 (2009) 121. - 28. FRANKLIN SS, LARSON MG, KHAN SA, WONG ND, LEIP EP, KANNEL WB, LEVY D, Circulation, 103 (2001) 1245. - 29. WILKING SV, BELANGER A, KANNEL WB, D'AGOSTINO RB, STEEL K, JAMA, 260 (1988) 3451.

\section{H. Vražić}

University of Zagreb, Dubrava University Hospital, Division of Cardiology, Department of Internal Medicine, Av. G. Šuška 6, 10000 Zagreb, Croatia e-mail:vrazic@gmail.com 


\section{PREVALENCIJA HIPERTENZIJE U HOSPITALIZIRANIH KORONARNIH BOLESNIKA U HRVATSKOJ}

Cilj ovog rada bio je istražiti pojavnost hipertenzije uz odabrane antropometrijske varijable u uzorku bolesnika hospitaliziranih zbog koronarne bolesti srca u Republici Hrvatskoj. U istraživanju su sudjelovali bolesnici hospitalizirani od 1. listopada 2007. g. do 7. siječnja 2010. g. zbog akutne ili kronične ishemijske bolesti srca u bolnicama diljem Hrvatske $(\mathrm{N}=1.298)$. Prevalencija hipertenzije u istraživanoj populaciji bila je visoka: čak $70,1 \%$ ispitanika imalo je povišene vrijednosti arterijskog tlaka ili od ranije postavljenu dijagnozu arterijske hipertenzije. Kod muških ispitanika srednje vrijednosti dijastoličkog arterijskog tlaka bile su statistički značajno više u odnosu na ispitanice $(78,91 \pm 8,97$ prema 77,12 $\pm 10,61 \mathrm{mmHg}, \mathrm{p}=0,011)$. Prevalencija hipertenzije bila je statistički značajno češća kod žena $(80,6 \%$ prema $65,8 \%, \mathrm{p}<0.001)$. Hipertenzija još uvijek predstavlja značajan problem u populaciji hospitaliziranih koronarnih bolesnika u Hrvatskoj. Nažalost, učestalost hipertenzije je u porastu u ovoj populaciji, što pokazuje i dalje postoje velike mogućnosti poboljšanja standarda preventivne kardiologije i u praksi već poduzetih mjera. 